\title{
Apilanurmen taloudellinen käyttöikä luomuviljelykierrossa
}

\author{
Asko Miettinen $^{1)}$, Kauko Koikkalainen ${ }^{2)}$, Arja Nykänen ${ }^{3)}$ \\ 1) Särkivaarantie 848,80910 Kulho, asko.miettinen@reppu.net \\ 2)MTT Taloustutkimus, Luutnantintie 13,00410 Helsinki, kauko.koikkalainen@mtt.fi \\ 3) MTT, Ekologinen tuotanto, $51900 J u v a$, arja.nykanen@mtt.fi
}

\section{Johdanto}

Suomen viljelyolosuhteissa nautakarjatiloilla nurmirehu on tuotannon perusrehu, jonka tuotannon järjestämisestä riippuu hyvin pitkälle tilan toiminnan kannattavuus. Tavanomaisessa tuotannossa nurmiviljely on viimeisten vuosikymmenten aikana perustunut pääasiassa heinäkasvien viljelyyn, mutta viime aikoina lähinnä ympäristösyiden ja typpilannoitteiden hinnan nousun myötä kiinnostus nurmipalkokasvien viljelyyn on jälleen herännyt. Nurmipalkokasvien juuriston typpeä sitovat bakteerit vähentävät typpilannoituksen tarvetta. EU:n mukanaan tuoma maatalouden toimintaympäristön muutos ohjaa tuotantoa myös vähemmän ostopanoksia käyttävään suuntaan. Samanaikainen maatalouden saaman tuen maksuperusteiden muutos tuotantomääriin sidotusta hintatuesta enemmän viljelypinta-ala ja eläinyksikköperusteiseksi siirtää tuotannon painopistettä laajaperäisemmäksi, jolloin kustannukset minimoimalla saavutetaan yleensä paras taloudellinen lopputulos. Tällöin luomutuotannosta on tullut suhteellisesti kilpailukykyisempi tuotantotapa.

Monivuotisten apilanurmien viljely ei kuitenkaan ole ongelmatonta. Nurmien apilapitoisuus vaihtelee vuosittain ja niiden tuottokyky heikkenee merkittävästi jo kolmantena nurmivuonna (Nykänen et al. 2000). Tällöin joudutaan miettimään erilaisia vaihtoehtoja nurmirehun tuotannon järjestämiseksi siten, että tuotanto olisi myös taloudellisesti kannattavaa. Luomutiloilla kiinnostus suuntautuu yksivuotisiin rehunurmiin.

Rehujen tuotantovaikutus perustuu pääasiassa sulavuuteen. Rehun sulavuus vaikuttaa siihen, kuinka paljon eläimelle käyttökelpoista energiaa ja ravintoaineita rehu sisältää sekä siihen, kuinka paljon eläin pystyy rehua syömään. Apilapitoisen rehun tuotantovaikutus on ollut parempi kuin yhtä sulavan pelkistä heinäkasveista tehdyn rehun (Heikkilä et al.1996). Tuotoslisäys on selittynyt sillä, että eläimet ovat pystyneet syömään apilarehuja enemmän kuin heinäkasveista tehtyjä rehuja.

Nykyään EU-tuet kattavat keskimäärin 40 \% luomumaitotilan tuloista ja näin ollen viljelijä pystyy vaikuttamaan omilla viljelyyn liittyvillä ratkaisuillaan noin $60 \%$ :iin tuloistaan (Koikkalainen \& Haataja 2000). Tämä ei todennäköisesti kannusta viljelijää parhaalla mahdollisella tavalla kehittämään tuotantoaan ja miettimään tilansa tuotantoratkaisuja sen jälkeen, kun on päättänyt tuotantosuunnan. Kuitenkin viljelijän, joka haluaa tuottaa hyvälaatuista maitoa ja lihaa, täytyy tuottaa myös laadukasta rehua eläimilleen. Tällöin tuotantoprosessit kannattaa suunnitella siten, että ne ovat mahdollisimman taloudellisia (pieni ry-hinta), turhaa työtä välttäviä ja laadukasta rehua tuottavia.

Kesäkuussa hyväksytty viimeinen EU:n yhteisen maatalouspolitiikan uudistusehdotus muuttaa maatalouden tukijärjestelmää entistä enemmän tuotantoalapohjaiseksi samalla kun tukimääriä pyritään asteittain pienentämään. Tämä tukiuudistus siirtää väistämättä maataloustuotannon suhteellista kannattavuutta vähän tuotantopanoksia käyttävän tuotannon suuntaan, jolloin apilapitoisen nurmen tuotannon taloudellinen kilpailuasema vahvistuu.

\begin{abstract}
Aineisto ja menetelmät
Laadukkaan luomurehun taloudelliset tuotantomallit -hankkeen talousosiossa on rakennettu LP-malli, jonka avulla arvioidaan apilanurmen taloudellisinta käyttöikää luonnonmukaisessa viljelykierrossa. Aineistona mallin rakentamisessa ovat olleet MTT Taloustutkimuksen luomutilamallit, Pro Agria Maaseutukeskusten liiton katetuottolaskelmia sekä MTT Ekologinen tuotannon nurmikasvien esikasviarvoa selvittäneestä tutkimuksesta ja "Palkokasvirehuun perustuva kotieläintuotanto - Legsil" hankkeesta saadut nurmisatotulokset.

Apilanurmikokeiden tuloksia oli saatavissa kahdelta paikkakunnalta, Mietoisista ja Juvalta. Mietoissa tehdyissä kenttäkokeissa puuttuu yhden vuoden tulokset kolmesta, joten mallin taustatiedoksi on valittu Juvalla suoritetuista kenttäkokeista saadut tulokset. Havainnoista, joita on kolmena kahden vuoden sarjana, saatavien eri-ikäisten nurmien keskiarvoja on käytetty lähtökohtana mallitarkastelulle.
\end{abstract}


Kenttäkokeiden satotasot ovat huomattavan korkeita verrattuna keskimääräisiin (TIKE 2003) satotasoihin, joten mallin avulla on testattu myös alempia satotasovaihtoehtoja.

Taulukko 1. Eri-ikäisten apilanurmien sadot (kg/ka) Juvalla ja Mietoisissa vuosina 1995 ja 1996 (Nykänen et al. 2000)

\begin{tabular}{|l|l|l|l|}
\hline Nurmisadot & 1v nurmi & 2v nurmi & 3v nurmi \\
\hline Juva 1995 & 6800 & 7000 & 6900 \\
\hline Juva 1996 & 4100 & 5900 & 5300 \\
\hline Mietoinen 1995 & 8400 & - & 7800 \\
\hline Mietoinen 1996 & 6500 & 8000 & 7900 \\
\hline
\end{tabular}

Taulukko 2. Mallissa lähtötasona käytetyt satotasot: vuodet 1-3 (Nykänen et al. 2000, MKL 2003), vuodet 4-6: mallille annettuja simuloinnin lähtötasoja.

\begin{tabular}{|l|r|r|r|r|r|r|}
\hline sadot & 1. vuosi & 2 vuosi & 3.vuosi & 4.vuosi & 5.vuosi & 6. vuosi \\
\hline kaura & 2800 & 2500 & 2100 & 1500 & 1000 & 500 \\
\hline apilanurmi & 5450 & 6450 & 6100 & 4000 & 3000 & 2000 \\
\hline ruis & 2240 & 2000 & 1600 & 1100 & 900 & 400 \\
\hline
\end{tabular}

Vaihtoehtoisina kasveina pellonkäytölle on mallissa käytetty 1-, 2-, 3- tai 4-vuotista apilaseosnurmea, rehukauraa ja viherkesantoa sekä mahdollisuutena on ollut myös rukiin viljely. Viljelykierron pituus on mallissa maksimissaan kuusi vuotta. Lisäksi, mallin antamien tulosten valossa pyritään arvioimaan apilan siemenen kylvön jaksotuksen sekä täydennyskylvön vaikutusta nurmen taloudelliseen käyttöikään. Apilanurmen, kuten rehunurmen yleensäkin, ikänä neljä vuotta on jo korkea ja apilanurmessa apilapitoisuuden lasku on erityisesti ongelma. Nurmen satotasoja neljännestä vuodesta eteenpäin simuloitiin muuttamalla asetettua lähtötasoa prosenttiyksikön välein.

Mallissa maksimoidaan viljelykierron tulosta, joka muodostuu eri kasvien tuottojen ja muuttuvien kustannusten erotuksena rajoitteena rehun tarve, peltoala. Lisäksi nurmen ikä on rajoitettu maksimissaan neljään vuoteen.

1) $\max \pi=\sum_{i=1}^{n} \sum_{j=1}^{t} a_{i j} p_{i j} y_{i j}-\sum_{i=1}^{n} \sum_{j=1}^{t} a_{i j} w_{i j} x_{i j}-\sum_{i=1}^{n} \sum_{j=1}^{t} C_{i j}$ ehdolla, että

2) $\sum_{i=1}^{n} \sum_{j=1}^{t} a_{i j}=A_{t o t}$

3) $\sum_{j=1}^{t} a_{i j}=1 \forall i \leq n$

4) $A_{i j} \leq \sum_{j=1}^{4} a_{i j}$ э $i=g$

jossa

$\pi=$ viljelykierron tuotto

$\mathrm{a}_{\mathrm{ij}}=$ kasvin $i$ pinta-ala kierron jaksona $j$

$\mathrm{g}=2 ;$ (apilanurmi)

$\mathrm{p}_{\mathrm{ij}}=$ kasvin $i$ hinta kierron jaksona $j$

$\mathrm{y}_{\mathrm{ij}}=$ kasvin $i$ satotaso kierron jaksona $j$

$\mathrm{w}_{\mathrm{ij}}=$ kasvin $i$ panoshinnat kierron jaksona $j$

$\mathrm{x}_{\mathrm{ij}}=$ kasvin $i$ tuotantopanokset kierron jaksona $j$

$\mathrm{C}_{\mathrm{ij}}=$ kasvin $i$ kiinteät kustannukset kierron jaksona $j$

$\mathrm{A}_{\mathrm{ij}}=$ viljelykierron kokonaisala

$\mathrm{A}_{\text {tot }}=$ viljelykierron kokonaisala 


\section{Tulokset ja tulosten tarkastelu}

Kun nurmen taloudellista ikää arvioitiin kenttäkoetulosten mukaisilla satotasoilla, vahvimmalle pääsi 2-vuotinen nurmi, jolloin nurmen perustamiskustannukset - kyntö ja muokkaus, lannoitus eli karjanlanta, kylvö, heinän- ja apilansiemen sekä kalkitus - olivat puolittuneet ja tuotto oli vielä riittävä kustannusten peittämiseksi. Tarkasteluun vaikuttaa kuitenkin hyvin vahvasti satotasotietojen tarkkuus: nyt käytettävissä olevat tiedot perustuvat kolmen vuoden tuloksiin, jolloin niitä voidaan pitää lähinnä suuntaa antavina.

Satotasoja simuloitiin vaihtoehtoisesti eri-ikäisillä nurmilla, jotta voitiin selvittää satotason vaikutusta taloudelliseen nurmen ikään. Mitä korkeammat nurmen satotasot ovat kierron ensimmäisinä vuosina suhteessa myöhempiin vuosiin, sen lyhyempi on nurmen taloudellinen käyttöikä. Mallitarkastelussa todettiin, että kun kolmannen vuoden satotasoa alennettiin mallin lähtötasosta 8,9\%, lyheni nurmen taloudellinen ikä vuodella. Päinvastainen kehitys puolestaan antaa todistusta nurmikierron pidentämisen puolesta. Nurmen taloudellinen ikä näytti lyhenevän myös silloin, kun kierron nurmisatoja pienennettiin samassa suhteessa eri vuosina. Samoin vaikutus näkyi myös pellon käytössä: leipäviljan viljely väheni samoin kuin viherkesannon osuus.

Apilan siemenenmäärän kylvön jakamista eri vuosille ei tässä vaiheessa voitu suoraan tutkia empiirisen aineiston pohjalta, joten tilannetta simuloitiin muuttamalla nurmien satotasoja. Em. menetelmä näyttäisi suosivan pitempää nurmen ikää: satotason todennäköinen aleneminen ensimmäisinä vuosina vahvistaa kierron myöhempien vuosien suhteellista kannattavuutta. Vaikutukset kustannuksiin tulevat lähinnä lisääntyneen työmenekin kautta, ellei myös apilan siemenen kokonaismäärää lisätä. Apilan siemenen täydennyskylvöä simuloitiin nostamalla kolmannen ja neljännen vuoden satotasoja. Täydennyskylvön $(2 \mathrm{~kg} / \mathrm{ha})$ vaikutus näyttäisi olevan samansuuntainen kuin siemenmäärän jakamisessakin: nurmen taloudellinen käyttöikä mahdollisesti kasvaisi. Mallin tulosten valossa, odotettavissa olevan sadon olisi oltava kuitenkin yli kuusinkertainen ilman täydennystä saatavaan satoon, jotta täydennyskylvö olisi kannattavaa. Toisin sanoen satotason pitäisi kohota noin 90\%:een toisen vuoden satotasosta.

Apilanurmen suhteellista kannattavuutta muihin rehukasveihin nähden arvioitiin muuttamalla mallissa apilan hintaa. Hintamuutosta ei voida pitää konkreettisena vaihtoehtona vaan pikemminkin keinona arvioida sitä miten herkkä apila on suhteellisille hintamuutoksille, kun otetaan huomioon biologiset kasvutekijä. Kun apilanurmen hintaa, jonka lähtötasona oli $0.11 € / \mathrm{kg} \mathrm{ka}^{1}$, alennettiin viljelykierron muiden kasvien hinnan pysyessä ennallaan, voitiin todeta, että nurmen osuus viljelykierrossa väheni, mutta hintamuutoksen piti olla kohtuullisen suuri: 30 prosenttia. Apilanurmen hinnan nostaminen mallissa vastaavasti kasvatti kannattavasti viljeltävissä olevaa nurmen ikää, mutta hinnan lähtötaso oli asettunut juuri 2- ja 3-vuotisten nurmen kannattavuusrajalle, jolloin jo 2\% muutos hinnassa ylöspäin lisäsi kannattavuuden riittäväksi 3-vuotiselle nurmelle. Seuraava kynnys 4-vuotisen nurmelle löytyikin vasta 21\%:n hinnannousun jälkeen.

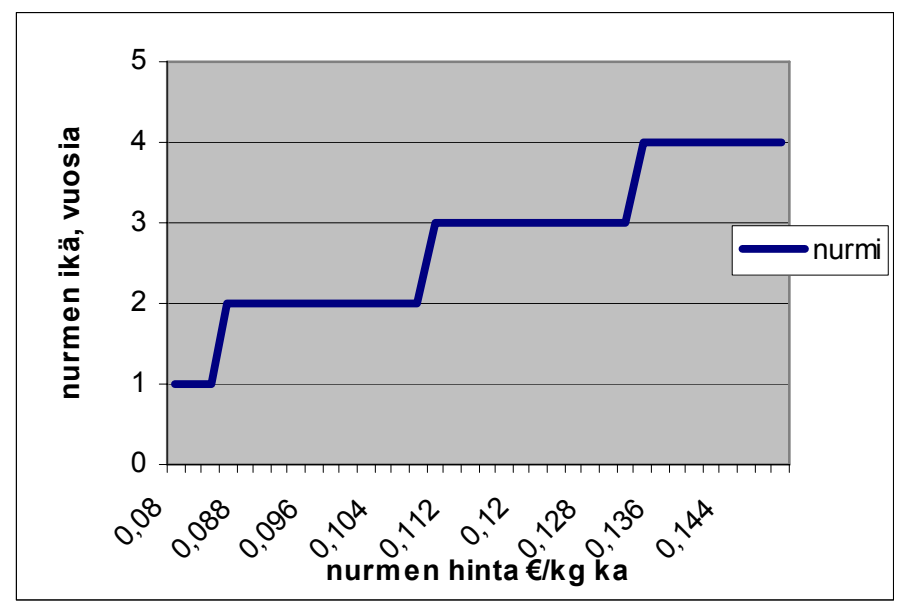

Kuva 1. Mallin mukainen nurmen hintamuutoksen vaikutus kannattavaan nurmen ikään.

Kun mallilla arvioitiin kustannusten alenemisen vaikutusta apilanurmen taloudelliseen ikää, voitiin todeta, että muuttuvien kustannusten oli alettava yli neljännes (27\%) ennen kuin nurmen käyttöikä li-

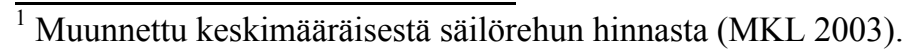


sääntyi vuodella. Kustannusten nousu mallilla lasketuissa arviossa osoittautui vielä jäykemmäksi, sillä nurmen perustamis- ja hoitokustannukset saivat nousta jopa $40 \%$ ennen kuin nurmen ikä aleni vuodella. Tulokset ovat vielä suuntaa antavia ja tarvitaan lisä aineistoa eri-ikäisten apilanurmen sadon muodostuksesta sekä typensidonnasta, jotta tuottoja voidaan arvioida paremmin.

\section{Johtopäätökset}

Tulokset vahvistavat sen, että nurmen taloudellinen käyttöikä riippuu suurimmaksi osaksi vuotuisen sadon määrästä. Myös sadon laadulla on merkityksensä, mutta apilaseosnurmien tapauksessa määrä korreloi vahvasti myös apilapitoisuuden kautta laatuun. Tällä hetkellä ongelmana näyttää olevan apilan kasvun rajoittuminen kahteen kasvukauteen, jolloin nurmen perustamiskulujen vaikutus heikentää kannattavuutta. Taloudellista kannattavuutta enemmän apilanurmen ikään vaikuttanee kuitenkin maan tiivistyminen, mikä lienee suurin yksittäinen tekijä talvituhojen ohella. Mikäli täydennyskylvöllä voidaan päästä riittävään sadonlisään, on se varteenotettava vaihtoehto nurmen iän jatkamiseksi. Tämän selvittämiseksi tarvitaan vielä kenttäkoetuloksia, mutta mallisimulaatiot antavat rohkaisevia viitteitä tähän suuntaan. Samansuuntainen toimintamalli on myös kylvösiemenen jakamisessa eri vuosien osalle. Nämä toimenpiteet aiheuttavat lisäkustannuksia, mutta mallilla tehtyjen simulointien mukaan melko huomattavakaan kustannusnousu antaa pitempi-ikäisen nurmen kautta paremman tuloksen..

Tarkasteltaessa hintamuutoksia voitiin todeta, että mikäli eri-ikäisten nurmien satotasot oletetaan vakioiksi, ei nurmen taloudellinen käyttöikä muutu kovin herkästi. Jos pinta-ala on rajoittava tekijä, suhteellisesti edullisempi rehukasvi on herkemmin syrjäyttämässä nurmea viljelykierrosta. On kuitenkin otettava huomioon apilanurmen typensidontavaikutus, jonka taloudellista vaikutusta ei vielä tähän tarkasteluun saatu mukaan.

Tuotteen hinnan nousulle käänteinen, mutta samalla tavoin kannattavuutta parantava kustannusten aleneminen on hyvin epätodennäköistä käytännön viljelyssä. Luonnonmukaisessa tuotannossa suurin kustannussäästö on saavutettu jo siirtymävaiheen aikana, kun välilannoitteiden ja kemiallisten kasvinsuojeluaineiden käyttö on lopetettu. Rikkakasvien torjunta vaatii traktorityötä, joka puolestaan lisää kone-, polttoaine- ja työkustannuksia.

On syytä ottaa myös huomioon, minkä arvoiseksi sato arvotetaan: luomuviljelyssä karkearehujen saatavuus on pyrittävä turvaamaan pääasiassa tilalta saatavana rehuna, koska useimmiten luomulaatuista karkea rehua ei ole muutoin saatavilla. Jos rehun hinta arvotetaan sen ravintosisällön rehuyksikköarvojen suhteessa esim. viljaan, voi nurmirehun arvo jäädä sen todellista arvoa pienemmäksi. Markkinahinnan käyttäminen ei taas välttämättä ole mahdollista, ellei markkinoita ole tai kysyntä on merkittävästi tarjontaa suurempi, jolloin rehun arvo puolestaan ylikorostuu suhteessa tuotokseen.

\section{Kirjallisuus}

Heikkilä et al. 1996: Heikkilä, T., Toivonen, V., \& Mela, T. 1996. Effects of red clover-grass, grass and annual ryegrass silages with two concentrate levels on milk production. Grassland Science in Europe 1: 447-450.

Koikkalainen, K.\& Haataja, K. 2000. Luomukotieläintuotteiden tuotantokustannus. MTTL:n selvityksiä $8 / 2000.59$ s.

Nykänen et al. 2000: Nykänen, A., Granstedt, A., Laine, A., Kunttu, S. 2000. Yields and clover contents of leys of different ages in organic farming in Finland. Biological agriculture \& horticulture 18, 1: p. 55 - 66.

MKL 2003. Tuottopehtoori: katetuotto- ja tuotantokustannuslaskelmat. Viitattu18.11.2003. Julkaistu11.3.2003. Saatavilla Internetissä: http://www.maaseutukeskus.fi/julkaisut/tuottopehtori.htm

TIKE 2002. Maa-ja metsätalousministeriön tietopalvelukeskus, maataloustilastoja 2002. Satotilastot 2002; Sato koko maa. Viitattu 2.12.2003. Julkaistu 12.12.2002. Saatavilla Internetissä:

http://tike.mmm.fi/tiedotteet/kokomaan\%20sato\%202002\%20121202.pdf 